\title{
A Comparative Study of Pottery from Mersin-Yumuktepe and Arslantepe, Turkey
}

\author{
Alessandro Buccolieri ${ }^{*}$, Gianluca Bozzetti², Antonio Serra², Daniela Manno', \\ Isabella Caneva ${ }^{3}$, Federico Manuelli $^{3}$ \\ ${ }^{1}$ Dipartimento di Scienze e Tecnologie Biologiche e Ambientali, Università del Salento, Lecce, Italy \\ ${ }^{2}$ Dipartimento di Beni Culturali, Università del Salento, Lecce, Italy \\ ${ }^{3}$ Dipartimento di Scienze dell'Antichità, Sapienza Università di Roma, Roma, Italy \\ Email: ${ }^{*}$ alessandro.buccolieri@unisalento.it
}

Received 21 October 2014; revised 22 November 2014; accepted 20 December 2014

Academic Editor: Alfredo Castellano, Dipartimento di Matematica e Fisica, Università del Salento, Italy

Copyright (C) 2015 by authors and Scientific Research Publishing Inc.

This work is licensed under the Creative Commons Attribution International License (CC BY).

http://creativecommons.org/licenses/by/4.0/

(c) (i) Open Access

\section{Abstract}

The purpose of this paper is to present a summary of the application of non-destructive techniques used in a comparative study of eighty pottery fragments of the Chalcolithic period (5000 BC ca.) and Late Bronze Age (1650 - 1200 BC ca.), found in Mersin-Yumuktepe (Southern Turkey) and Arslantepe (Malatya, Eastern Turkey). The use of a scanning electron microscopy, equipped with a system of energy dispersive X-ray spectroscopy (SEM-EDX), has allowed determining their morphology, the main inclusions and the elemental composition of ceramic mixtures of each artifact. Moreover, the determination of majority and trace elements has revealed various information, such as the origin of raw materials or the contamination that occurred in the manufacturing phase. The multivariate statistical method has allowed highlighting similarities and/or differences among the ceramics.

\section{Keywords}

Anatolian, Mersin-Yumuktepe, Arslantepe, Pottery, SEM-EDX, Statistical Analysis, Archaeometric

\section{Introduction}

Since pottery, in all its shapes, has always followed through man's life, today the study of ceramic fragments found during excavations is, to an archaeologist, the key point of a careful historical reconstruction, useful to provide knowledge, which otherwise would have gone lost.

\footnotetext{
"Corresponding author.
}

How to cite this paper: Buccolieri, A., Bozzetti, G., Serra, A., Manno, D., Caneva, I., \& Manuelli, F. (2015). A Comparative Study of Pottery from Mersin-Yumuktepe and Arslantepe, Turkey. Archaeological Discovery, 3, 15-25. 
Each artifact of historical, archaeological and artistic interest contains, in fact, hidden information about its origin and its history, that can't be entirely learned only through the senses, needing instead an interdisciplinary approach (Rehren \& Pernicka, 2008; Moropoulon \& Polikreti, 2009). In particular, the use of structural and compositional analysis allows to study in detail the chemical composition of the artifacts and to achieve knowledge about the identity and origin of the raw materials, in some cases corresponding to their areas of production (Romich \& Weinmann, 2000; Faella et al., 2012), and to increase our understanding of the economic-political organization and of the cultural changes of an ancient people (Grave et al., 2008; Grave et al., 2009; Bong et al., 2010). These data may help to assess, where possible, the extent of the trade and/or the exchange of artifacts among cultural groups, including information on their technological capabilities and development, their work and life conditions, social differentiations and on the functional purposes of the products.

This methodological approach was used in the present study for the analysis of eighty pottery fragments found in Mersin-Yumuktepe (Southern Turkey) and Arslantepe (Malatya, Eastern Turkey), which cover a time span that ranges from the Chalcolithic period (5000 BC ca.) to the Late Bronze Age (1650 - 1200 BC ca.). Besides, both Anatolians sites, at a given time of their existence, were part of a common cultural-political framework that during the Late Bronze Age saw the expansion of the Hittite civilization in these territories (Ertem \& Demirci, 1999; Angle et al., 2002; Glatz, 2009).

Given that the use of non-destructive techniques is fundamentally important for archaeologists and, in general, for an archaeometric study (Bonissoni \& Ricci Bitti, 1988; Amelinckx et al., 1997; Ciliberto \& Spoto, 2000; Poupeau et al., 2010), in this chemical-physical and morphological analysis of the ceramics a central role has been given to a non-destructive analytical technique-the scanning electron microscopy-equipped with a system of energy dispersive X-ray spectroscopy (SEM-EDX).

The experimental results obtained have been later processed by using multivariate statistical techniques (Baxter, 1994; Frank \& Todeschini, 1994; Baxter, 1995; Lomiento, 2004; Varmuza \& Filzmoser, 2009), such as the Principal Component Analysis (PCA), in order to identify any similarities and/or differences among the analyzed samples; starting from an exhaustive list of chemical-physical data specific to each sample, we also focused on an integrated interpretation, consistent with an archaeological study. Finally, the statistical data processing has allowed the comparison between the material culture of two realities, geographically far away, but culturally close to each other.

\section{Materials and Methods}

\subsection{Sites and Samples}

Eighty pottery samples from the Anatolian peninsula were analyzed by using non-destructive techniques. These fragments are representative of some of the pottery classes found during the excavations of the sites of MersinYumuktepe (Caneva \& Sevin, 2004) and Arslantepe (Frangipane, 2004), two multi-layered settlement that go, roughly, from the Neolithic to the Middle Ages (Figure 1). In particular, the site of Yumuktepe is situated near the port city of Mersin, on the southern coast of Turkey. This area, located in a strategically important geographical position, that from the valleys of the Anatolian plateau leads to the coast and the Syro-Mesopotamian plain, has always been a nodal point for commercial traffics. The site of Arslantepe, instead, also called "the hill of the lions", is located in the village of Orduzu, in the southeast of the large and fertile Malatya plain (Eastern Turkey), an oasis in the chain of the Anti-Taurus, about fifteen kilometers from the right bank of the Euphrates and not far from the modern city.

The samples investigated come respectively from the levels of the Chalcolithic period and the Late Bronze Age of the two sites. In specific, they were classified as follows: 28 finds of the Late Bronze Age from site Arslantepe (in this paper indicated as Arslantepe LBA), 11 finds of the Late Bronze Age from site Mersin-Yumuktepe collected during the sampling of 2009 (in this paper indicated as Mersin LBA 2009), 16 finds of the Late Bronze Age from site Mersin-Yumuktepe from the sampling of 2008 (in this paper indicated as Mersin LBA 2008), 13 finds of the Chalcolithic period from site Mersin-Yumuktepe sampled in 2009 (in this paper indicated as Mersin C 2009) and 12 finds of the Chalcolithic period from site Mersin-Yumuktepe collected during the sampling of 2012 (in this paper indicated as Mersin C 2012).

\subsection{Methodologies}

A scanning electron microscope with X-ray microanalysis of the JEOL (JEOL Ltd., Tokyo, Japan), model 


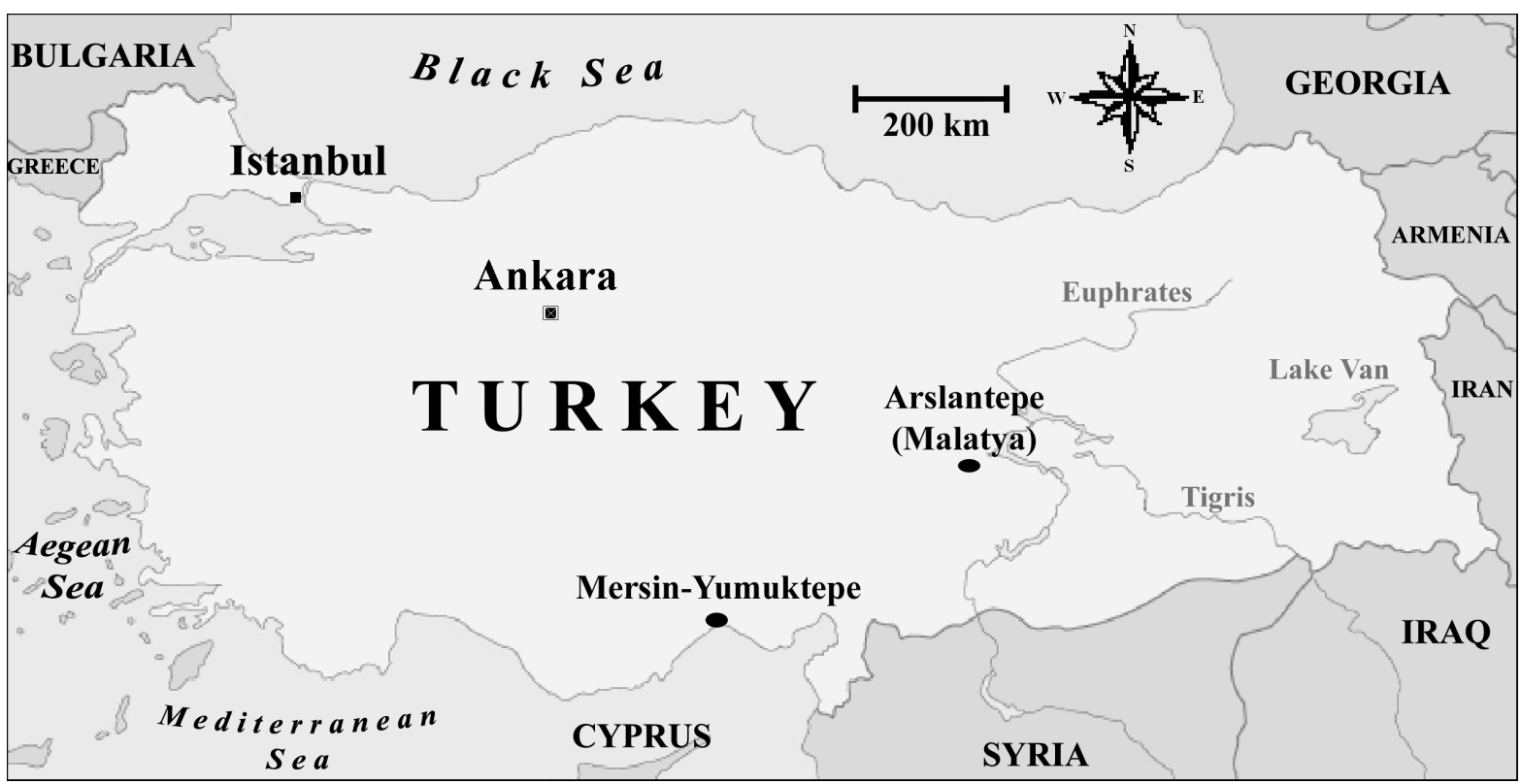

Figure 1. Map of the two excavation sites, Mersin and Malatya (Arslantepe).

SEM-EDX JSM-5410LV was used for archaeometric investigation. It has provided very useful data about the morphology, particle size and chemical composition of main and minority elements. In particular, the determination of majority and in trace elements has revealed information about the origin of raw materials and the contamination occurred in the manufacturing phase, being helpful to understand the manufacturing technology used in that period and the economic development of the sites.

The SEM was used at a pressure of $30 \mathrm{~Pa}$ with a $20 \mathrm{kV}$ accelerating voltage, which is the usual voltage for ceramic analysis. To ensure a good homogeneity and statistically significant results concerning the elemental analysis, for each sample were chosen regions with dimension equal to $150 \times 100 \mu \mathrm{m}^{2}$. Measurements were made at various working distances to cover the range of possibilities that might be used in future examinations of fractured objects. All internal and external surfaces and sections of the samples have been treated pre-emptively through a mechanical cleaning before analysis.

$\mathrm{Na}, \mathrm{Mg}, \mathrm{Al}, \mathrm{Si}, \mathrm{S}, \mathrm{K}, \mathrm{Ca}, \mathrm{Ti}, \mathrm{Mn}$ and Fe were calibrated using default calibrations generated by the Oxford Instruments EDX INCA Analyser software. The results were converted into oxide percentages, which were normalized (oxygen by stoichiometry) to account, due to the fact that oxygen and carbon were not measured. All analyses were carried out on unprepared surfaces and not polished samples and the results are regarded as semiquantitative (Spataro et al., 2009; Spataro et al., 2013). Then, it was determined the relative concentration of the oxides by recording the EDX spectrum (with an acquisition time equal to three minutes) on forty regions randomly selected. The SEM images were obtained without pretreatment of the samples and by using backscattered electrons in a condition of low vacuum. The vacuum is indispensable in order to prevent possible phenomena of loading surface that can complicate the morphological analysis (Von Zglinicki, 1993).

Experimental results of chemical composition obtained by SEM-EDX were processed with multivariate statistical method by using the software STATISTICA ${ }^{\circledR}$ (StatSoft Inc., Tulsa, OK, USA), in order to identify possible similarities and/or differences among the analyzed samples.

\section{Experimental Results and Discussion}

The scanning electron microscopy has enabled a morphological and compositional analysis of the internal and external surfaces and of the sections of the eighty samples analyzed. Figure 2 and Figure 3 show two typical SEM images, respectively of the surface (sample n. 11 Arslantepe LB) and of the section (sample n. 4 Arslantepe LB) of the pottery object of this study.

The morphological analysis has allowed to obtain a complete examination of the grain size of the ceramic bodies and, in addition, the identification of the shape and the composition of the present inclusions such as, for 


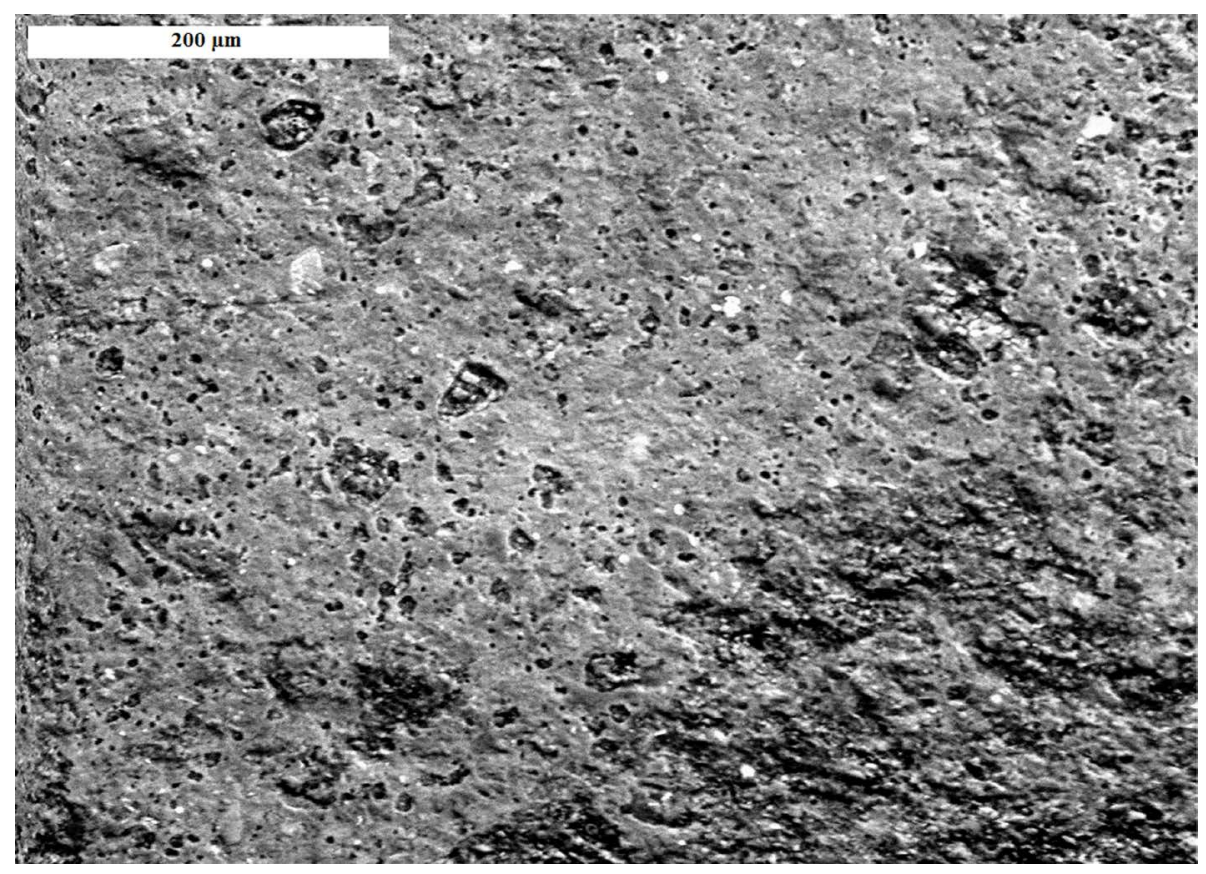

Figure 2. Typical SEM image of the surface of a pottery fragment.

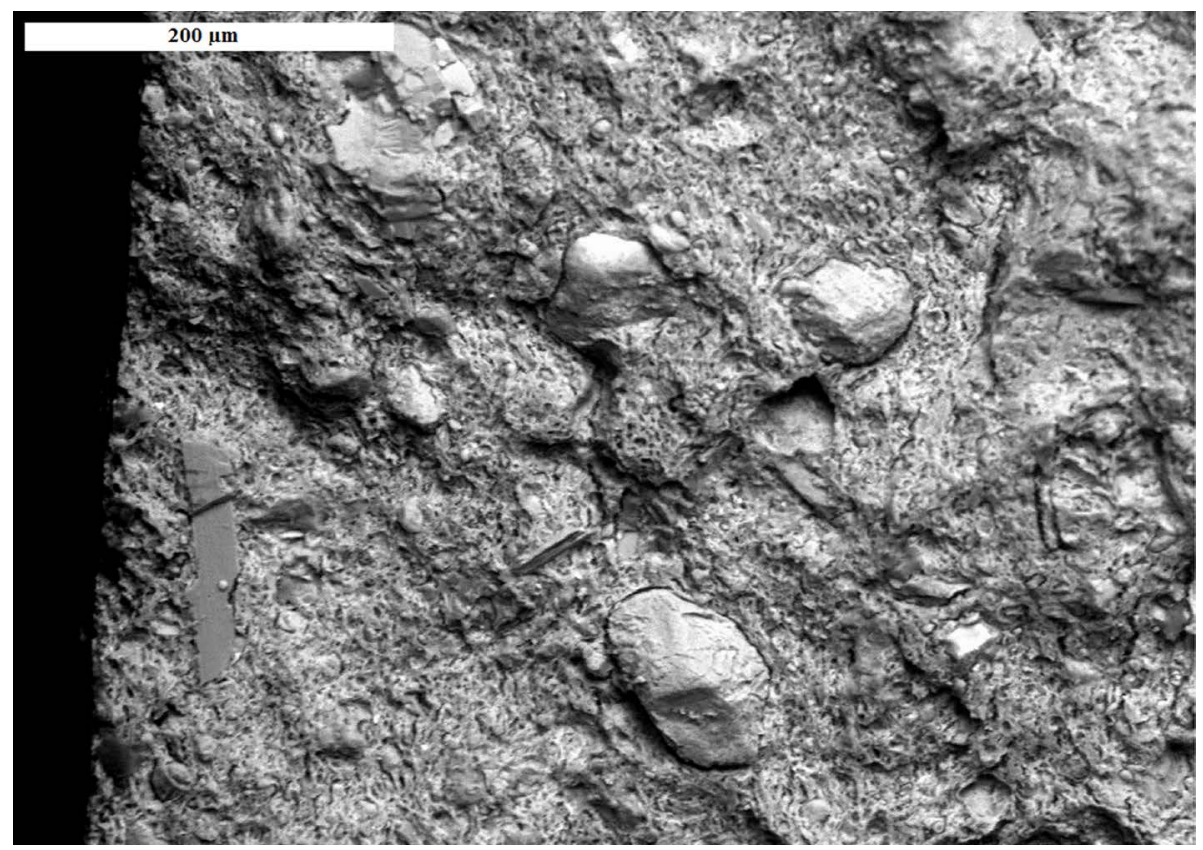

Figure 3. Typical SEM image of the section of a pottery fragment.

example, crystallites of various nature. Table 1 summarizes main inclusions highlighted in the analyzed samples.

Overall, in the samples, it has been revealed a hiatal granulometry (with granulometric phases of various sizes) consisting of a basic binder phase with fine grain. In particular, it has a clayey material to which has been added a temper fraction coarser and in variable quantities, consisting of sand, inclusions and fossil of several origins.

Table 2 summarizes the semi-quantitative values of the concentration (\% w/w) of $\mathrm{Na}_{2} \mathrm{O}, \mathrm{MgO}, \mathrm{Al}_{2} \mathrm{O}_{3}, \mathrm{SiO}_{2}$, $\mathrm{SO}_{3}, \mathrm{~K}_{2} \mathrm{O}, \mathrm{CaO}, \mathrm{TiO}_{2}, \mathrm{MnO}$ and $\mathrm{Fe}_{2} \mathrm{O}_{3}$ for each sample, the results of which are reported as normalized\% oxides. Each value represents the average of five measurements obtained by using the EDX analysis performed on the 
Table 1. Main inclusions present in analyzed samples.

\begin{tabular}{|c|c|c|}
\hline \multicolumn{2}{|c|}{ Sample } & Kind of the crystallites (inclusions) \\
\hline \multirow{28}{*}{ Arslantepe LBA } & 1 & $\mathrm{Fe}$ and $\mathrm{Ca}$ \\
\hline & 2 & $\mathrm{Fe}$ and $\mathrm{Ca}$ \\
\hline & 3 & $\mathrm{Fe}, \mathrm{Ca}$ and $\mathrm{S}$ \\
\hline & 4 & Crystallites of different kinds \\
\hline & 5 & $\mathrm{Fe}$ \\
\hline & 6 & $\mathrm{Fe}$ \\
\hline & 7 & $\mathrm{Fe}$ \\
\hline & 8 & $\mathrm{Ca}$ \\
\hline & 9 & $\mathrm{Fe}$ \\
\hline & 10 & Ca and P \\
\hline & 11 & $\mathrm{Ca}$ \\
\hline & 12 & $\mathrm{~Pb}, \mathrm{Fe}$ and $\mathrm{C}$ \\
\hline & 13 & Fe and Mn \\
\hline & 14 & $\mathrm{Ti}$ and $\mathrm{Fe}$ \\
\hline & 15 & $\mathrm{Ti}$ and $\mathrm{Ca}$ \\
\hline & 16 & $\mathrm{Ca}, \mathrm{C}$ and $\mathrm{Fe}$ \\
\hline & 17 & $\mathrm{Ti}$ and $\mathrm{Fe}$ \\
\hline & 18 & Crystallites of different kinds \\
\hline & 19 & Fe, Ca, Ti, Mg, K and S \\
\hline & 20 & Crystallites of different kinds; $\mathrm{Fe}$ and $\mathrm{Ti}$ \\
\hline & 21 & Ca and S \\
\hline & 22 & $\mathrm{Fe}$ \\
\hline & 23 & $\mathrm{Fe}$, Ca and S \\
\hline & 24 & $\mathrm{Fe}, \mathrm{Ti}, \mathrm{Ca}, \mathrm{Si}$ and $\mathrm{Al}$ \\
\hline & 25 & $\mathrm{P}, \mathrm{Ca}, \mathrm{Fe}$ and $\mathrm{Mn}$ \\
\hline & 26 & $\mathrm{Ca}$ \\
\hline & 27 & $\mathrm{~S}$ and $\mathrm{Ca}$ \\
\hline & 28 & Fe and S \\
\hline \multirow{13}{*}{ Mersin C 2009} & 1 & Crystallites of different kinds \\
\hline & 2 & $\mathrm{Cr}$ \\
\hline & 3 & Crystallites of different kinds \\
\hline & 4 & Crystallites of different kinds \\
\hline & 5 & $\mathrm{Si}, \mathrm{Ca}$ and $\mathrm{Fe}$ \\
\hline & 6 & Crystallites of different kinds \\
\hline & 7 & Crystallites of different kinds \\
\hline & 8 & Crystallites of different kinds \\
\hline & 9 & $\mathrm{Cu}, \mathrm{Zn}$ and $\mathrm{Na}$ \\
\hline & 10 & $\mathrm{Cu}, \mathrm{Zn}, \mathrm{Ca}$ and $\mathrm{Na}$ \\
\hline & 11 & Crystallites of different kinds \\
\hline & 12 & $\mathrm{Cr}, \mathrm{Fe}$ and $\mathrm{Mn}$ \\
\hline & 13 & Crystallites of different kinds \\
\hline
\end{tabular}




\section{Continued}

\begin{tabular}{|c|c|c|}
\hline \multirow{12}{*}{ Mersin C 2012} & 1 & $\mathrm{Ca}$ and $\mathrm{Fe}$ \\
\hline & 2 & Crystallites of different kinds \\
\hline & 3 & $\mathrm{Ca}, \mathrm{Ti}$ and $\mathrm{Fe}$ \\
\hline & 4 & Crystallites of different kinds \\
\hline & 5 & Crystallites of different kinds \\
\hline & 6 & $\mathrm{Ca}$ and $\mathrm{Fe}$ \\
\hline & 7 & Crystallites of different kinds \\
\hline & 8 & $\mathrm{Ca}, \mathrm{Si}$ and $\mathrm{Fe}$ \\
\hline & 9 & $\mathrm{Ca}, \mathrm{Fe}$ and $\mathrm{Cr}$ \\
\hline & 10 & Fe and $\mathrm{Ti}$ \\
\hline & 11 & $\mathrm{Ca}, \mathrm{Fe}$ and $\mathrm{Ba}$ \\
\hline & 12 & Ca, Fe and $\mathrm{Ti}$ \\
\hline \multirow{16}{*}{ Mersin LBA 2008} & 1 & Shells and fragments of wood \\
\hline & 2 & Shells \\
\hline & 3 & Fe and $\mathrm{Zn}$ \\
\hline & 4 & Crystallites of different kinds \\
\hline & 5 & Crystallites of different kinds \\
\hline & 6 & Crystallites of different kinds \\
\hline & 7 & Mg, P, Fe, Mn and Cr, Radiolaria \\
\hline & 8 & Shells \\
\hline & 9 & Crystallites of different kinds \\
\hline & 10 & Crystallites of different kinds \\
\hline & 11 & Crystallites of different kinds \\
\hline & 12 & $\mathrm{Fe}, \mathrm{Cr}$, Ti and $\mathrm{Mg}$ \\
\hline & 13 & Crystallites of different kinds \\
\hline & 14 & Crystallites of different kinds \\
\hline & 15 & Shells, Ca \\
\hline & 16 & Fragments of bone and wood, Fe \\
\hline \multirow{11}{*}{ Mersin LBA 2009} & 1 & Crystallites of different kinds \\
\hline & 2 & $\mathrm{Al}, \mathrm{Ca}, \mathrm{Fe}$ and $\mathrm{Si}$ \\
\hline & 3 & Crystallites of different kinds \\
\hline & 4 & Crystallites of different kinds \\
\hline & 5 & Crystallites of different kinds \\
\hline & 6 & $\mathrm{Si}, \mathrm{S}$, calcium carbonate, bone fragments \\
\hline & 7 & Ca, straw \\
\hline & 8 & Crystallites of different kinds \\
\hline & 9 & Crystallites of different kinds, radiolaria carbonatic composition \\
\hline & 10 & Crystallites of different kinds \\
\hline & 11 & Crystallites of different kinds \\
\hline
\end{tabular}


Table 2. Semi-quantitative values of $\mathrm{Na}_{2} \mathrm{O}, \mathrm{MgO}, \mathrm{Al}_{2} \mathrm{O}_{3}, \mathrm{SiO}_{2}, \mathrm{SO}_{3}, \mathrm{~K}_{2} \mathrm{O}, \mathrm{CaO}, \mathrm{TiO}_{2}, \mathrm{MnO}$ and $\mathrm{Fe}_{2} \mathrm{O}_{3}$ concentrations (\% w/w) obtained by SEM-EDX. The results are reported as normalized \% oxides.

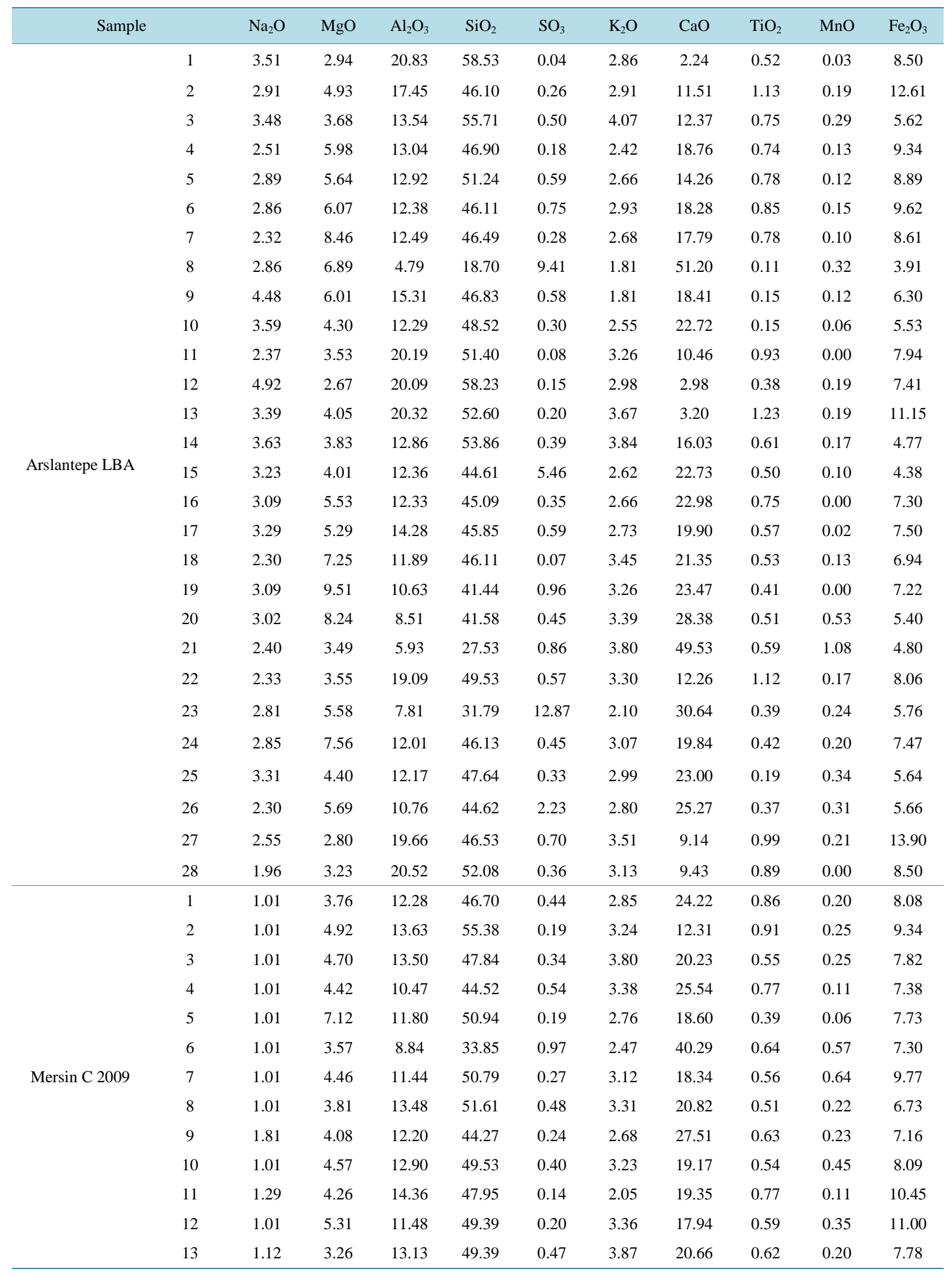




\section{Continued}

\begin{tabular}{|c|c|c|c|c|c|c|c|c|c|c|c|}
\hline \multirow{12}{*}{ Mersin C 2012} & 1 & 3.21 & 6.36 & 10.31 & 39.49 & 0.46 & 2.52 & 30.67 & 0.48 & 0.35 & 6.14 \\
\hline & 2 & 2.03 & 5.62 & 11.59 & 44.37 & 0.27 & 4.06 & 25.23 & 0.45 & 0.21 & 6.17 \\
\hline & 3 & 2.33 & 4.81 & 12.69 & 46.07 & 0.26 & 2.75 & 23.34 & 0.66 & 0.24 & 6.84 \\
\hline & 4 & 2.83 & 4.93 & 9.94 & 39.34 & 0.69 & 3.45 & 32.08 & 0.75 & 0.12 & 5.87 \\
\hline & 5 & 2.95 & 4.78 & 10.29 & 42.89 & 0.44 & 2.64 & 27.99 & 0.76 & 0.37 & 6.88 \\
\hline & 6 & 2.63 & 5.40 & 9.28 & 37.14 & 0.66 & 2.63 & 35.96 & 0.58 & 0.26 & 5.46 \\
\hline & 7 & 2.43 & 4.89 & 10.69 & 44.90 & 0.12 & 2.68 & 28.64 & 0.38 & 0.08 & 5.20 \\
\hline & 8 & 2.90 & 5.00 & 11.11 & 40.00 & 0.29 & 4.65 & 29.72 & 0.56 & 0.15 & 5.62 \\
\hline & 9 & 2.09 & 5.15 & 9.91 & 43.33 & 0.81 & 3.76 & 21.14 & 0.71 & 0.86 & 12.25 \\
\hline & 10 & 2.49 & 5.40 & 13.83 & 50.02 & 0.45 & 4.16 & 13.44 & 1.01 & 0.46 & 8.74 \\
\hline & 11 & 2.31 & 5.22 & 11.91 & 45.81 & 1.86 & 3.56 & 19.61 & 1.83 & 0.20 & 7.70 \\
\hline & 12 & 2.76 & 5.31 & 13.68 & 48.51 & 0.25 & 3.81 & 17.44 & 0.73 & 0.13 & 7.38 \\
\hline \multirow{16}{*}{ Mersin LBA 2008} & 1 & 2.51 & 3.52 & 10.24 & 41.93 & 0.28 & 3.28 & 29.72 & 0.61 & 0.33 & 7.58 \\
\hline & 2 & 2.60 & 5.11 & 10.31 & 43.43 & 0.31 & 3.62 & 25.77 & 0.54 & 0.64 & 7.68 \\
\hline & 3 & 2.36 & 5.12 & 12.44 & 48.04 & 0.35 & 4.15 & 18.17 & 0.77 & 0.33 & 8.26 \\
\hline & 4 & 2.52 & 4.54 & 11.70 & 48.19 & 0.51 & 4.51 & 18.13 & 0.75 & 0.14 & 9.00 \\
\hline & 5 & 2.50 & 4.87 & 12.72 & 47.92 & 0.82 & 3.30 & 20.48 & 0.73 & 0.25 & 6.41 \\
\hline & 6 & 2.21 & 4.82 & 11.97 & 46.58 & 0.20 & 3.82 & 19.10 & 0.89 & 0.35 & 10.06 \\
\hline & 7 & 2.27 & 3.93 & 12.26 & 47.72 & 0.41 & 3.17 & 20.27 & 0.61 & 0.62 & 8.74 \\
\hline & 8 & 2.90 & 3.97 & 14.46 & 52.84 & 0.38 & 4.59 & 14.77 & 0.62 & 0.23 & 5.25 \\
\hline & 9 & 2.29 & 3.76 & 13.22 & 49.60 & 0.27 & 5.16 & 17.36 & 0.66 & 0.08 & 7.61 \\
\hline & 10 & 2.09 & 5.02 & 10.64 & 47.84 & 0.18 & 4.41 & 17.57 & 0.76 & 0.73 & 10.76 \\
\hline & 11 & 1.73 & 4.76 & 11.71 & 47.48 & 0.39 & 4.53 & 18.37 & 0.76 & 0.41 & 9.86 \\
\hline & 12 & 2.17 & 4.14 & 12.87 & 47.11 & 0.79 & 4.19 & 19.82 & 0.55 & 0.15 & 8.23 \\
\hline & 13 & 2.31 & 5.91 & 12.78 & 50.63 & 0.23 & 3.62 & 14.68 & 0.60 & 0.29 & 8.96 \\
\hline & 14 & 1.93 & 4.57 & 11.88 & 47.53 & 0.39 & 4.91 & 19.62 & 0.67 & 0.23 & 8.29 \\
\hline & 15 & 2.08 & 3.15 & 7.46 & 29.99 & 1.74 & 2.61 & 44.92 & 0.27 & 0.82 & 6.95 \\
\hline & 16 & 1.91 & 3.96 & 16.43 & 49.61 & 0.71 & 3.94 & 14.85 & 0.74 & 0.16 & 7.68 \\
\hline \multirow{11}{*}{ Mersin LBA 2009} & 1 & 2.53 & 5.00 & 12.35 & 44.34 & 0.38 & 3.42 & 24.17 & 0.74 & 0.05 & 7.02 \\
\hline & 2 & 2.63 & 5.72 & 11.78 & 42.60 & 2.64 & 3.42 & 24.80 & 0.52 & 0.18 & 5.71 \\
\hline & 3 & 2.27 & 5.53 & 13.91 & 51.90 & 0.25 & 4.68 & 12.33 & 0.82 & 0.15 & 8.16 \\
\hline & 4 & 2.27 & 4.64 & 11.62 & 45.65 & 0.43 & 2.95 & 23.46 & 0.65 & 0.15 & 8.16 \\
\hline & 5 & 2.01 & 5.42 & 11.60 & 47.99 & 0.27 & 4.03 & 17.61 & 0.79 & 0.49 & 9.78 \\
\hline & 6 & 2.51 & 4.80 & 11.23 & 44.62 & 0.06 & 3.71 & 23.95 & 0.74 & 0.10 & 8.28 \\
\hline & 7 & 2.18 & 5.32 & 11.87 & 44.99 & 1.48 & 3.57 & 22.01 & 0.55 & 0.15 & 7.87 \\
\hline & 8 & 2.53 & 5.27 & 13.31 & 50.27 & 0.18 & 3.30 & 16.84 & 0.69 & 0.13 & 7.48 \\
\hline & 9 & 2.59 & 4.91 & 12.19 & 46.18 & 0.37 & 2.87 & 22.16 & 0.73 & 0.14 & 7.85 \\
\hline & 10 & 2.18 & 4.97 & 11.07 & 45.87 & 0.44 & 3.36 & 23.86 & 0.95 & 0.18 & 7.11 \\
\hline & 11 & 2.13 & 5.14 & 13.95 & 52.48 & 0.42 & 3.80 & 13.41 & 0.67 & 0.18 & 7.82 \\
\hline
\end{tabular}


internal section of each sample.

Although the results show a substantial homogeneity among different samples, it is possible to highlight a difference between the two pottery productions. The mean value of the concentration of $\mathrm{Na}_{2} \mathrm{O}, \mathrm{MgO}, \mathrm{Al}_{2} \mathrm{O}_{3}$, $\mathrm{SiO}_{2}, \mathrm{SO}_{3}, \mathrm{~K}_{2} \mathrm{O}, \mathrm{CaO}, \mathrm{TiO}_{2}, \mathrm{MnO}$ and $\mathrm{Fe}_{2} \mathrm{O}_{3}$ are equal respectively to $2.23 \% \pm 1.09 \%, 4.93 \% \pm 1.25 \%, 12.61 \%$ $\pm 3.05 \%, 46.24 \% \pm 6.24 \%, 0.83 \% \pm 1.83 \%, 3.34 \% \pm 0.70 \%, 21.08 \% \pm 8.68 \%, 0.66 \% \pm 0.25 \%, 0.25 \% \pm 0.21 \%$ and $7.73 \% \pm 1.86 \%$. Therefore, for each sample, silicon, calcium, aluminum and iron are majority elements, while titanium, manganese, potassium, sulfur, magnesium and sodium are minority elements and/or trace elements.

The average concentrations of the oxides, determined on the internal section of each ceramic object, were further processed by using the multivariate statistical method of the Principal Component Analysis (PCA). For this purpose we used a matrix consisting of eighty cases (analyzed samples) and ten variables (determined oxides) and the first four main components have been extracted, obtaining a coverage of the total variance equal to $75 \%$.

Figure 4 shows the loading of variables on the first two main components, which separate the concentrations of the oxides along the two factors (Factor 1 and Factor 2). The graph allows discriminating the concentration of oxides detected, more specifically $\mathrm{SiO}_{2}$ and $\mathrm{Al}_{2} \mathrm{O}_{3}$ have negative values of the first principal component, while $\mathrm{CaO}$ and $\mathrm{SO}_{3}$ have positive values of it. $\mathrm{MnO}$ has negative values on the second principal component, while $\mathrm{Na}_{2} \mathrm{O}$ has positive values on the second principal component.

Figure 5 summarizes the results obtained with the PCA method and it allows making some important considerations.

Firstly, it is possible to demonstrate among the analyzed findings, a difference between the two pottery productions: in fact, all the samples of Arslantepe except three (n. 2, n. 21 and n. 27 Arslantepe LB) have positive values on the PC2, while the samples from Mersin-Yumuktepe have almost all (45 out of 62 ceramics, approximately 73\%) negative values on the same component. Seventeen ceramics from Mersin-Yumuktepe, instead, have a positive value on the PC2 and they overlap with the group of Arslantepe.

The percentages of the oxides detected, therefore, let us infer that the material used for the manufacturing of the finds from Mersin-Yumuktepe have a common origin, as well as substantially common seems to be also the

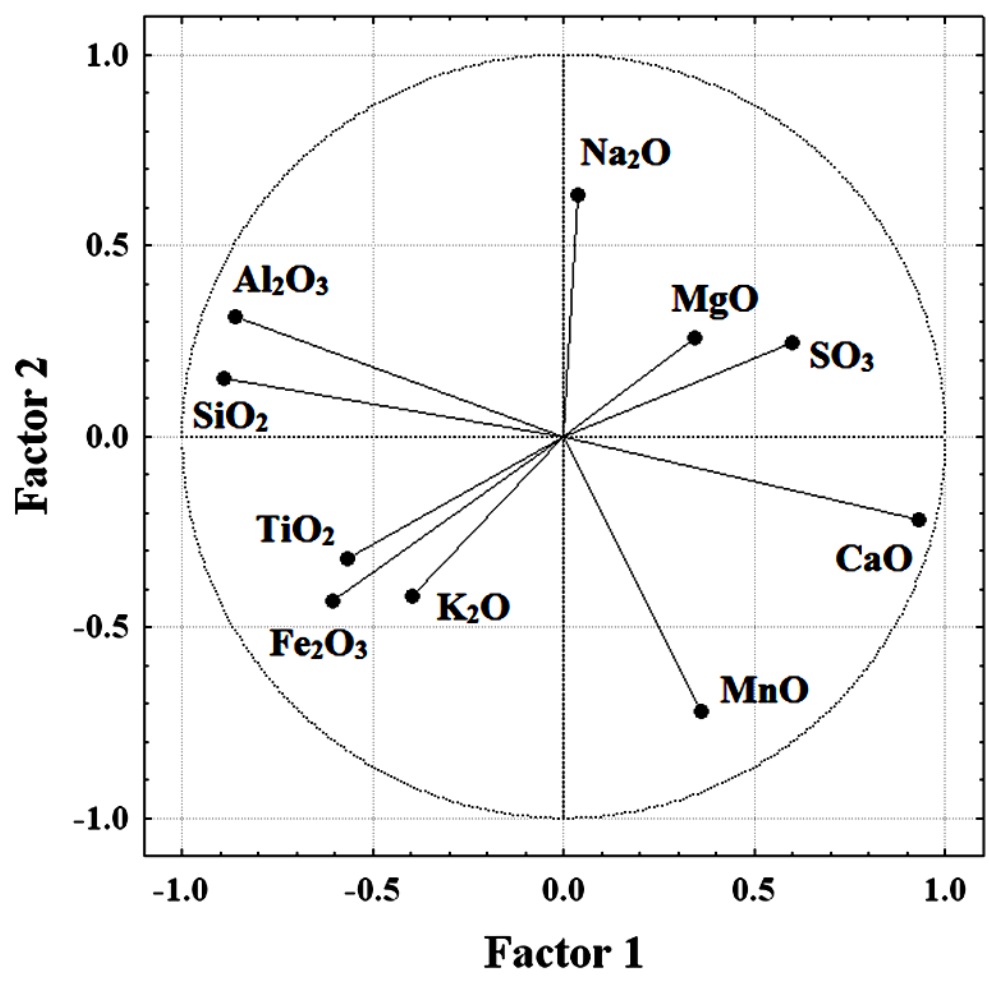

Figure 4. Loading of variables on the first two principal components. 


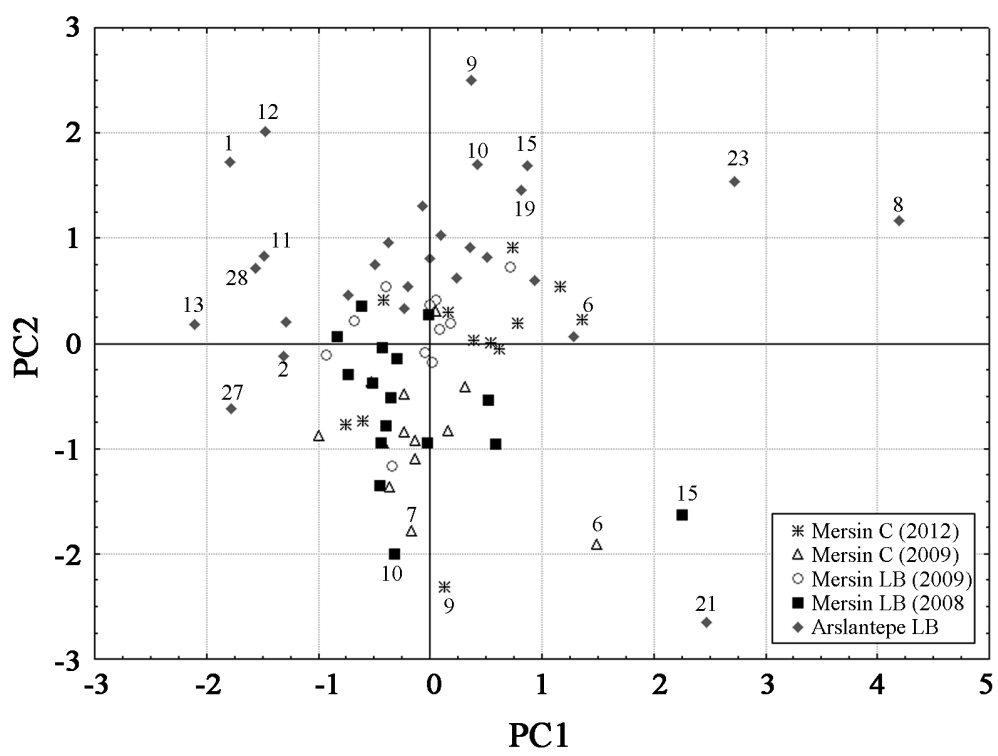

Figure 5. Scatter plot of the scores for the first two principal components.

origin of the raw material used for the production of the finds of Arsalentepe. However, these two types of material are different from each other.

An important element is then given by samples n. 8 and n. 23 (Arslantepe LB) which significantly deviate by the general trend for higher concentrations of $\mathrm{CaO}$, the first, and especially of $\mathrm{SO}_{3}$, the latter. The same appliesalso to samples n. 15 (Mersin LB 2008), n. 21 (Arslantepe LB) and n. 6 (Mersin C 2009), which have higher average concentration of $\mathrm{CaO}$ and $\mathrm{MnO}$, but scarce of $\mathrm{SiO}_{2}$. The samples $\mathrm{n} .1$ and $\mathrm{n}$. 12 (Arslantepe $\mathrm{LB}$ ) have, instead, high concentration of $\mathrm{SiO}_{2}$ and $\mathrm{Al}_{2} \mathrm{O}_{3}$, but low concentration of $\mathrm{CaO}$, while the samples n. 9 (Arslantepe LB), n. 9 (Mersin C 2012) and n. 13 (Arslantepe LB) show, respectively, the highest average concentration of $\mathrm{Na}_{2} \mathrm{O}$ and $\mathrm{Fe}_{2} \mathrm{O}_{3}$ (the first two) and of $\mathrm{Fe}_{2} \mathrm{O}_{3}$ compared to the rest of the finds analyzed. This can be substantially attributed to the use of clays from different sources, which let us assume a non-local production of some of these ceramics.

Nonetheless, our hypothesis must consider that the various qualitative and quantitative composition of pottery mixture may respond to different uses of the finished products. Overall, the differences observed in the ceramic mixture take into account the heterogeneity of the considered context.

The maximum output to this work is given, however, only by the results of the samples of Mersin-Yumuktepe. In fact, almost all samples from the latter show values that fall within -1 and 1 of the PC1 and PC2. This indicates a considerable homogeneity from the compositional point of view of the pottery production. The population of Mersin, in fact, from the Chalcolithic period (5000 BC ca.) until the Late Bronze Age (1650-1200 BC ca.) and, therefore, for more than 3500 years, has allegedly used the same techniques and the same raw materials for the realization of pottery.

This observation probably indicates the use of the same technology for firing the pottery, but this does not prove that all materials investigated were produced by the same furnace.

\section{Conclusion}

The archaeometric method used in this work has allowed us to learn important information on the morphology, particle size and chemical composition of the studied ceramic objects.

The simultaneous use of non-destructive techniques, relatively quick and inexpensive, and the subsequent statistical processing of the experimental results obtained made it possible to suggest some important assessments and to highlight some key elements, such as the difference between the pottery production of Mersin-Yumuktepe and Arslantepe and the probable millenary productive continuity only of the pottery of Mersin-Yumuktepe. This result is fundamental in the determination of a historical/archaeological framework of these two sites.

The methodology followed in this study can certainly be applied to other archaeological contexts and to other artifacts of historic and artistic interest such as, for instance, glass, sediments and coins. 


\section{References}

Amelinckx, S., van Dyck, D., van Landuyt, J., \& van Tendeloo, G. (1997). Electron Microscopy: Principles and Fundamentals (p. 527). Wiley: VCH. http://dx.doi.org/10.1002/9783527614561

Angle, M., Morbidelli, P., \& Palmieri, A. M. (2002). Pottery from Arslantepe (Malatya, Turkey): Petrographic Features and Archaeological Data. Periodico di Mineralogia, 71, 43-71.

Baxter, M. J. (1994). Exploratory Multivariate Analysis in Archaeology (p. 307). Edinburgh University Press.

Baxter, M. J. (1995). Standardization and Transformation in Principal Component Analysis, with Applications to Archaeometry. Applied Statistics, 44, 513-527. http://dx.doi.org/10.2307/2986142

Bong, W. S. K., Matsumura, K., Yokoyama, K., \& Nakai, I. (2010). Provenance Study of Early and Middle Bronze Age Pottery from Kaman-Kalehöyük, Turkey, by Heavy Mineral Analysis and Geochemical Analysis of Individual Hornblende Grains. Journal of Archaeological Science, 37, 2165-2178. http://dx.doi.org/10.1016/j.jas.2010.03.013

Bonissoni, G., \& Ricci Bitti, R., (1988). La diffrattometria dei raggi X per materiali policristallini (p. 214 ). In T. Nuove (Ed.). Milano: Tecniche Nuove.

Caneva, I., \& Sevin, V. (2004). Mersin-Yumuktepe a Reappraisal (p. 176). Congedo ed., Galatina.

Ciliberto, E., \& Spoto, G. (2000). Modern Analytical Methods in Art and Archaeology (p. 736). Canada: John Wiley \& Sons.

Ertem, E., \& Demirci, S. (1999). Characteristics of Hittite Pottery Sherds from Sites in the Kizılırmak Basin. Journal of Archaeological Science, 26, 1017-1023. http://dx.doi.org/10.1006/jasc.1999.0425

Faella, G., Frunzio, G., Guadagnuolo, M., Donadio, A., \& Ferri, L. (2012). The Church of the Nativity in Bethlehem: NonDestructive Tests for the Structural Knowledge. Journal of Cultural Heritage, 13, 27-41. http://dx.doi.org/10.1016/j.culher.2012.10.014

Frangipane, M. (2004). Arslantepe. Alle origini del potere. Arslantepe, la collina dei leoni (p. 207). Milano: Mondadori Electa s.p.a.

Frank, I. E., \& Todeschini, R. (1994). The Data Analysis Handbook (p. 339). Amsterdam: Elsevier Science B.V.

Glatz, C. (2009). Empire as Network: Spheres of Material Interaction in Late Bronze Age Anatolia. Journal of Anthropological Archaeology, 28, 127-141. http://dx.doi.org/10.1016/j.jaa.2008.10.003

Grave, P., Kealhofer, L., Marsh, B., \& Gates, M. H. (2008). Using Neutron Activation Analysis to Identify Scales of Interaction at Kinet Höyük, Turkey. Journal of Archaeological Science, 35, 1974-1992. http://dx.doi.org/10.1016/j.jas.2008.01.001

Grave, P., Kealhofer, L., Marsh, B., Sams, G. K., Voigt, M., \& DeVries, K. (2009). Ceramic Production and Provenience at Gordion, Central Anatolia. Journal of Archaeological Science, 36, 2162-2176. http://dx.doi.org/10.1016/j.jas.2009.05.029

Lomiento, V. (2004). Codifica e trattamento automatico dei dati nelle discipline umanistiche. Principi, metodi e applicazioni (p. 124). Bari: Edipuglia.

Moropoulon, A., \& Polikreti, K. (2009). Principal Component Analysis in Monument Conservation: Three Application Examples. Journal Cultural Heritage, 10, 73-81. http://dx.doi.org/10.1016/j.culher.2008.03.007

Poupeau, G., Le Bourdonnec, F. X., Carter, T., Delerue, S., Shackley, M. S., Barrat, J. A., Dubernet, S., Moretto, P., Calligaro, T., Milic, M., \& Kobayashi, K. (2010). The Use of SEM-EDS, PIXE and EDXRF for Obsidian Provenance Studies in the Near East: A Case Study from Neolithic Çatalhöyük (Central Anatolia). Journal of Archaeological Science, 37, 2705-2720. http://dx.doi.org/10.1016/j.jas.2010.06.007

Rehren, T. H., \& Pernicka, E. (2008). Coins, Artefacts and Isotopes-Archaeometallurgy and Archaeometry. Archaeometry, 50, 232-248. http://dx.doi.org/10.1111/j.1475-4754.2008.00389.x

Romich, H., \& Weinmann, A. (2000). Laser Cleaning of Stained Glass Windows. Overview on an Interdisciplinary Project. Journal Cultural Heritage, 1, 151-154. http://dx.doi.org/10.1016/S1296-2074(00)00186-2

Spataro, M., Meeks, N., \& Meek, A. S. (2013). Scientific Investigation of Faience Fragments Attributed to the Town Mosaic at Knossos. Archaeometry, 55, 910-922. http://dx.doi.org/10.1111/j.1475-4754.2012.00721.x

Spataro, M., Meeks, N., Bimson, M., Dawson, A., \& Ambers, J. (2009). Early Porcelain in Seventeenth-Century England: Non-Destructive Examination of Two Jars from Burghley House. The British Museum, Technical Research Bulletin, 3, 37-46.

Varmuza K., \& Filzmoser, P. (2009). Introduction to Multivariate Statistical Analysis in Chemometrics (p. 321). Boca Raton, FL: CRC Press.

Von Zglinicki, T. (1993). Radiation Damage and Low Temperature X-Ray Microanalysis. In D. C. Sigee, A. J. Morgan, A. T. Warley, \& Y. A. Sunmner (Eds.), X-Ray Microanalysis in Biology. Experimental Techniques and Applications (pp. 117132). Cambridge: Cambridge University Press. 
Scientific Research Publishing (SCIRP) is one of the largest Open Access journal publishers. It is currently publishing more than 200 open access, online, peer-reviewed journals covering a wide range of academic disciplines. SCIRP serves the worldwide academic communities and contributes to the progress and application of science with its publication.

Other selected journals from SCIRP are listed as below. Submit your manuscript to us via either submit@scirp.org or Online Submission Portal.
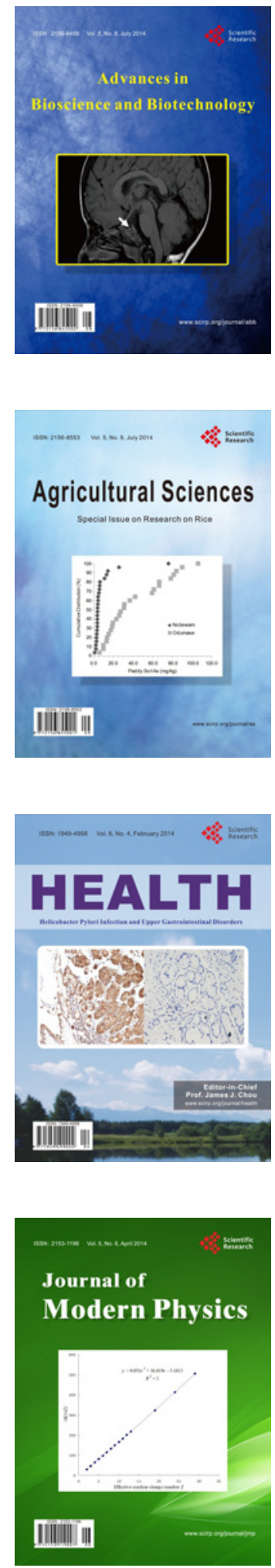
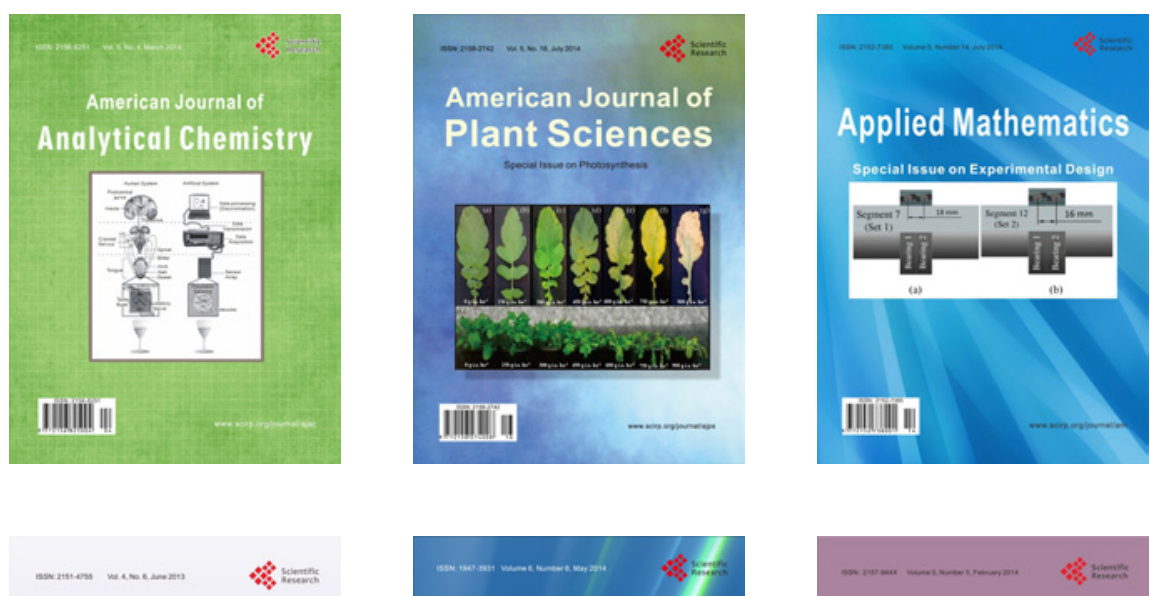

Creative Education
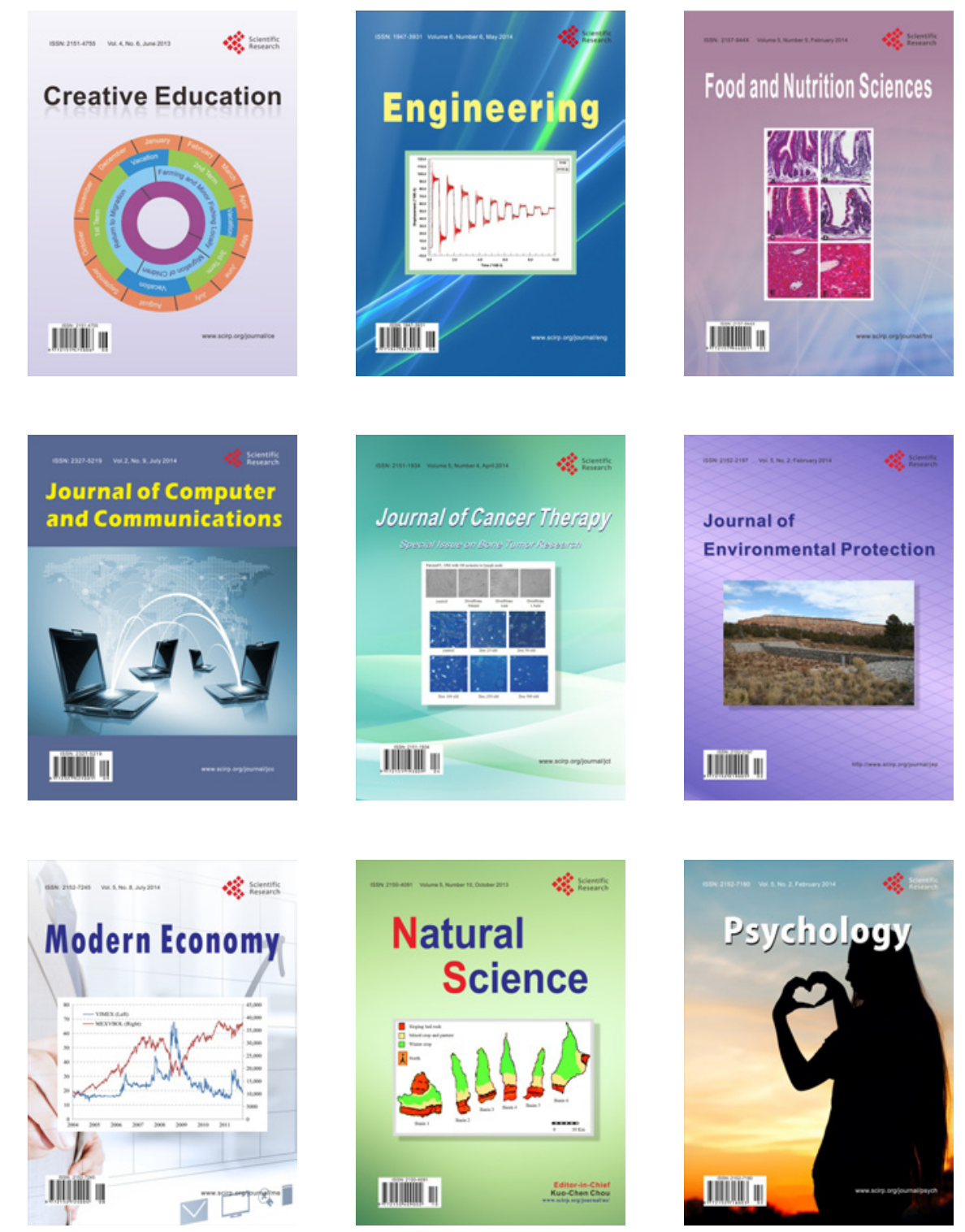